\title{
INDEKS MASSA TUBUH BERPENGARUH TERHADAP USIA MENARCHE PADA SISWI KELAS 5 DAN 6 DI SDN 01 WIYUNG SURABAYA
}

\author{
Fitria Rakhmawati Putri*, Wesiana** \\ UNUSA, FKK, Prodi SI Keperawatan - Jl. Smea 57 Surabaya \\ wesiana@yahoo.co.id
}

\begin{abstract}
Menarche is the first menstruation confirming the sexual maturity in adolescents. Nearly half of the female students having menarche earlier at the age of $\leq$ 10 years are overweight. Therefore, the purpose of this study was to find out the correlation between Body Mass Index (BMI) and age at menarche in the fifth and sixthgrade female students studying at SDN 01 Wiyung Surabaya (State Elementary School).

The type of study was analytic. The population involved all of the fifth and sixth-grade female students studying at the elementary school mentioned above having menarche in the last month, totally 17 respondents which were taken as the samples by using total sampling technique. The independent variable was BMI, whereas the dependent one was age at menarche. The data were collected by doing interview and observation. Moreover, they were analyzed by using Spearman's Rank test with the significance level $\alpha=0.05$.

The result of study showed that nearly all of the respondents (76.5\%) had BMI with obesity and early menarche. Furthermore, the result of Spearman Rank test showed that $p$ $=0.003$ and $\alpha=0.05$ which meant that $p<\alpha$ so that $H_{0}$ was rejected stating that there was a correlation between the Body Mass Index (BMI) and age at menarche in the fifth and sixth-grade female students studying at SDN 01 Wiyung Surabaya.

The conclusion of study was that the adolescents having higher BMI tend to have menarche earlier. Therefore, the adolescents are expected to keep maintain the menu of balanced foods.
\end{abstract}

ABSTRAK: Menarche adalah mentruasi pertama kali yang menunjukkan kematangan seksual pada remaja. Hampir setengah siswi yang menarche lebih dini usianya $\leq 10$ tahun, hal tersebut banyak ditemukan pada anak yang memiliki berat badan berlebih. Tujuan penelitian untuk mengetahui hubungan antara IMT dengan usia menarche pada siswi kelas 5 dan 6 di SDN 01 Wiyung Surabaya.

Penelitian menggunakan analitik. Populasinya siswi kelas 5 dan di SDN 01 Wiyung Surabaya. yang sudah mengalami menarche 1 bulan terakhir sebesar 17 responden, sempel seluruh siswi yang sudah menarche, dengan tehnik Total Sampling. Variabel bebas adalah IMT, variabel tergantung adalah usia menarche. Data di kumpulkan dengan wawancara dan observasi, di analisis menggunakan Uji Rank Spearman, dengan $\alpha=0,05$

Hasil penelitian menunjukkan hampir seluruh responden $(76,5 \%)$ mengalami IMT kegemukan dan menarche dini. Hasil Uji Rank Spearman didapatkan bahwa $\rho=0,003$ dan $\alpha=0,05$ berarti $\rho<\alpha$ maka $\mathrm{H}_{0}$ ditolak yang menyatakan ada hubungan antara IMT dengan usia menarche pada siswi kelas 5 dan 6 di SDN 01 wiyung Surabaya.

Simpulannya adalah remaja yang memiliki IMT yang lebih tinggi cenderung mendapatkan menarche terlebih awal. Diharapkan untuk remaja menjaga menu makana seimbang.

Kata kunci : IMT (Indeks Massa Tubuh), menarche, dan siswi. 


\section{PENDAHULUAN}

Masa remaja merupakan transisi dari anak-anak menuju masa remaja, yang berawal pada usia 9-10 tahun dan berakhir diusia 18 tahun. Pada masa remaja terjadi puncak pertambahan berat badan dan tinggi badan yaitu pada wanita pada usia 12 tahun, sedangkan pada remaja pria terjadi pada usia 14 tahun (Arisman, 2004). Masa perkembangan dan pertumbuhan yang dialami remaja dapat menjadi masalah pada perkembangan awal terutama pada remaja putri, permasalan tersebut diantaranya perkembangan dan pertumbuhan organ fisik maupun biologisnya seperti payudara yang membesar, pinggul yang membesar, atau terjadinya menstruasi pertama kali yang biasa disebut dengan menarche.

Menarche muncul pada usia 10-15 tahun pada masa pubertas, namun saat ini cukup banyak ditemukan remaja yang mengalami menarche lebih dini usia $\leq 10$ tahun dan hal tersebut banyak ditemukan pada anak yang memiliki berat badan berlebih. Sesuai dengan perkembangan zaman usia menarche pada remaja turut mengalami penurunan yang cukup signifikan, dari rata-rata 14 tahun menjadi 12,8 tahun (Silva dalam Pujiani, 2012). Hasil RISKESDAS 2010 menunjukkan bahwa $37,5 \%$ rata-rata usia menarche pada anak Indonesia adalah 13-14 tahun dengan kejadian awal pada usia kurang dari 9 tahun dan ada yang lambat sampai 20 tahun. Di Provinsi Jawa Timur rata-rata usia menarche sebesar 36,5\% pada usia 13-14 tahun, sebesar 2,3\% pada usia 9-10 tahun dan $0,1 \%$ pada usia 6-8 tahun

Ada banyak faktor yang mempengaruhi usia menarche, diantaranya : status gizi, penyakit, kelainan fisik, audio visual, lingkungan sosial, genetik, dan psikologi. Status gizi dapat diinterpretasikan dari indeks antropometri berat badan menurut IMT. Berat badan dapat mempengaruhi status gizi dalam kaitannya terhadap usia menarche. Menurut Acharya, dkk. Dalam Pujiani (2012) perbaikan nutrisi akan berdampak kepada penurunan usia menstruasi pertama. Menarche dini lebih cenderung ditemui pada wanita dengan status nutrisi yang baik atau lebih. Menurut Winkjasastro (2005), usia menarche memang bervariasi, akan tetapi akhir-akhir ini usia menarche semakin cepat. Hal ini disebabkan oleh adanya adypocyte-derived hormone leptin yang diduga dapat mempengaruhi masa awal menarche. Peningkatan kadar leptin dalam darah dapat menyebabkan peningkatan kadar LH yang berhubungan dengan peningkatan estradiol dan awal menarche, hal ini lebih beresiko terjadi pada anak dengan berat badan berlebih atau obesitas (Edward dalam Siti Aishah,2011). Dari hasil observasi dan wawancara dengan 10 siswi kelas 5 dan 6 di SDN 1 Wiyung, didapatkan 7 siswi sudah mengalami menarche pada usia $<10$ tahun. Berdasarkan observasi dari 10 siswi tersebut didapatkan 6 siswi memiliki berat badan rata-rata $\geq 60 \mathrm{~kg}$ dan tinggi badan rata-rata $148 \mathrm{~cm}$.

Menarche dini dapat berpengaruh pada perubahan secara cepat dan mendadak yang mempengaruhi psikologi karena anak belum siap menerima kedatangan menstruasi. Masalah fisik yang mungkin timbul adalah kurangnya kebersihan diri (personal hygiene) sehingga dapat berisiko terjadinya infeksi saluran kemih (ISK) (Atikah dan Maisaroh, 2009). Sedangkan menurut Helm dalam Pujiani (2012), usia menarche dini merupakan faktor resiko terjadinya kanker ovarium. Oleh karena itu, tenanga kesehatan hendaknya dapat memberikan penyuluhan tentang menarche dikalangan remaja putri, baik dari faktorfaktor yang mempengaruhi serta akibatnya. Peran orang tua dan guru sebagai pendidik juga tak luput untuk menciptakan lingkungan dimana mereka merasa aman untuk bertanya dan mendapatkan bimbingan, maka diharapkan kepada orang tua dan pendidik mampu menciptakan lingkungan adaptif bagi anak dan anak didiknya, agar masalah yang terjadi terutama pada hal usia menarche 
yang berhubungan dengan berat badan tersebut dapat ditanggulangi dengan perbaikan status gizi. Oleh karena itu penulis ingin meneliti tentang hubungan antara IMT dengan usia menarche pada siswi kelas 5 dan 6 di SDN 01 Wiyung Surabaya.

\section{METODE}

Penelitan dilakukan pada siswi kelas 5 dan 6 di SDN 1 Wiyung Surabaya. Waktu penelitian dilaksanakan pada bulan Juli 2014. Jenis penelitian analitik, di observasi secara bersamaan dengan metode pendekatan cross sectional. Populasi dalam penelitian ini adalah siswi kelas 5 dan 6 di SDN 1 Wiyung Surabaya yang sudah mengalami menarche 1 bulan terakhir sebesar 17 orang. Besar sampel sebagian siswi kelas 5 dan 6 SDN 1 Wiyung Surabaya yang sudah mengalami menstruasi \pm 1 bulan yang lalu. Sampel diambil dengan menggunakan teknik Total Sampling. Variabel Independen : Indeks Massa Tubuh. Variabel Dependen : Usia Menarche.

\section{HASIL}

Hasil penelitian yang telah dilakukan pada juli 2014 dengan jumlah responden sebanyak 17 siswi kelas 5 dan 6 di SDN 01 Wiyung Surabaya. Data hasil penelitian data khusus terdiri dari klasifikasi IMT (indeks masa tubuh) dan kategori usia menarche.

a. Klasifikasi IMT (indeks masa tubuh)

Pengelompokan IMT (Indeks Masa Tubuh) berdasarkan klasifikasi dari WHO (2010).

Tabel 5.3 Distribusi Frekuensi Responden Berdasarkan Klasifikasi IMT pada Siswi Kelas 5 dan 6 di SDN 01 Wiyung Surabaya

\begin{tabular}{lrr}
\hline Klasifikasi & Jumlah & Persentase (\%) \\
\hline Kurus & 0 & 0 \\
Normal & 4 & 23,5 \\
Kegemukan & 13 & 76,5 \\
Obesitas & 0 & 0 \\
\hline Jumlah & 17 & 100 \\
\hline \multicolumn{2}{c}{ Sumber: Data Prime, Juli 2014 }
\end{tabular}

Sumber: Data Prime, Juli 2014
Berdasarkan tabel 5.3 menunjukkan hampir seluruh responden 13 (76,5\%) mengalami kategori IMT kegemukan.

b. Usia Menarche

Pengelompokan usia menarche menurut Wiknjosastro (2005) dibagi menjadi 3 yaitu dini, normal, dan tarda. Usia menarche dini $\leq 10$ tahun, menarche normal usia 11-13 tahun, sedangkan usia menarche tarda $\geq 14$ tahun.

Tabel 5.4 Distribusi Frekuensi Responden Berdasarkan Usia Menarche pada Siswi Kelas 5 \& 6 di SDN 01 Wiyung Surabaya

\begin{tabular}{lrr}
\hline Kategori & Jumlah & Persentase (\%) \\
\hline Dini & 13 & 76,5 \\
Normal & 4 & 23,5 \\
Tarda & 0 & 0 \\
\hline Jumlah & 17 & 100
\end{tabular}

Sumber: Data Primer, Juli 2014

Tabel 5.4 menunjukkan bahwa hampir seluruh responden $13(76,5 \%)$ mengalami menarche dini.

c. Hubungan IMT dengan usia menarche

Data ini menggambarkan hubungan antar variabel yang diukur dan disajikan dalam bentuk tabulasi silang, data tersebut meliputi hubungan IMT dengan usia menarche.

Tabel 5.5 Tabulasi Silang Hubungan IMT dengan Usia Menarche pada Siswi Kelas 5 dan 6 di SDN 01 Wiyung Surabaya

\begin{tabular}{|c|c|c|c|c|c|c|c|c|}
\hline \multirow{3}{*}{ IMT } & \multicolumn{6}{|c|}{ Usia Menarche } & \multicolumn{2}{|c|}{ Jumlah } \\
\hline & \multicolumn{2}{|c|}{ Dini } & \multicolumn{2}{|c|}{ Normal } & \multicolumn{2}{|c|}{ Tarda } & & \\
\hline & $\mathrm{N}$ & $\%$ & $\mathrm{~N}$ & $\%$ & $\mathrm{~N}$ & $\%$ & $\mathrm{~N}$ & $\%$ \\
\hline Kurus & 0 & 0 & 0 & 0 & 0 & 0 & 0 & 0 \\
\hline Norm & 1 & 25,0 & 3 & 7 & 0 & 0 & 4 & 100 \\
\hline al & 12 & 92,3 & 1 & 5 , & 0 & 0 & 1 & 100 \\
\hline Kege & 0 & 0 & 0 & 0 & 0 & 0 & 3 & 0 \\
\hline muka & & & & 7 , & & & 0 & \\
\hline $\mathrm{n}$ & & & & 7 & & & & \\
\hline Obesit & & & & 0 & & & & \\
\hline as & & & & & & & & \\
\hline Jumla & 13 & 76,5 & 4 & 2 & 0 & 0 & 1 & 100 \\
\hline $\mathrm{h}$ & & & & $\begin{array}{r}3, \\
5\end{array}$ & & & 7 & \\
\hline
\end{tabular}

Sumber : DataPrimer, Juli 2014

Tabel 5.5 menunjukkan bahwa dari 13 responden yang mengalami kegemukan didapatkan hampir seluruhnya 12 (92,3\%) mengalami menarche dini. Sedangkan dari 
4 responden yang mengalami IMT normal didapatkan sebagian besar responden $3(75 \%)$ mengalami usia menarche normal.

Dari tabel tersebut, kemudian di analisis menggunakan uji statistik Rank Spearman. Perhitungan dengan SPSS 16,0 for windows didapatkan bahwa $\rho=0,003$ dan $\alpha=0,05$ berarti $\rho<\alpha$ maka $\mathrm{H}_{0}$ ditolak yang menyatakan ada hubungan antara IMT dengan usia menarche pada siswi kelas 5 dan 6 di SDN 01 wiyung Surabaya. Dimana responden yang mengalami kegemukan cenderung mengalami menarche dini.

\section{PEMBAHASAN}

1. IMT (Indeks Massa Tubuh)

Berdarkan tabel 5.3 dapat diketahui bahwa hampir seluruh responden 13 (76,5\%) memiliki klasifikasi IMT kegemukan. Kegemukan adalah peningkatan berat badan melebihi batas kebutuhan skeletal dan fisik sebagai akibat akumulasi lemak berlebihan dalam tubuh. Kegemukan dapat di ukur dengan menggunakan perbandingan berat badan (BB) dan tinggi badan (TB). Kegemukan di tentukan dari nilai IMT 25,10-34,99. Dari hasil penelitian peneliti memperoleh nilai kegemukan tertinggi 27,80 dan nilai kegemukan terkecil 25,10. Dengan nilai rata-rata dari IMT kegemukan 26,34.

Sebagian remaja mempunyai kebiasaan yang tidak benar yaitu suka sekali mengkonsumsi makanan siap saji dan makanan kecil yang penuh kalori atau sering disebut dengan ngemil. Saat ini banyak didapatkan penjual makanan siap saji dilingkungan sekolah, hal tersebut juga di dapatkan di SDN 01 Wiyung Surabaya. Para siswa atau siswi di SDN 01 Wiyung Surabaya hampis seluruhnya membeli makanan siap saji di lingkungan sekolah. Kondisi ini dapat memicu anak membeli makanan siap saji sehingga menyebabkan anak menjadi gemuk, apalagi jika kebiasaan tersebut tidak disertai dengan kegiatan olahraga yang teratur. Hal ini sesuai dengan teori Dorland
(2006) dalam Soelistyaningsih (2012) bahwa asupan kalori yang masuk melalui makanan lebih banyak daripada jumlah yang digunakan akan mengakumulasi lemak berlebih dalam tubuh.

Penelitian ini di tunjang oleh penelitian Puji (2008), terhadap 110 responden siswi kelas V dan VI SDN 2 Banyuwangi dapat diketahui nilai IMT $<25$ terdapat 24 $(21,8 \%)$ responden, nilai IMT 18,5 - 25 terdapat $34(30,9 \%)$ responden dan 52 $(47,3 \%)$ responden dengan IMT $>25,10$.

Penelitain penunjang dari penelitian Abimanyu (2006), terhadap 43 responden siswi SLTP 2 Magetan diperoleh kategori Indeks Massa Tubuh responden terbanyak adalah kegemukan dengan jumlah 28 $(53.8 \%)$ responden. Didapatkan juga ratarata Indeks Massa Tubuh responden adalah 25,88 .

Dari hasil analisis univariat penelitian yang dilakukan oleh Albert (2010), didapatkan hanya 7 responden saja yang memiliki IMT Normoweight, sedangkan yang terbanyak justru Obese 1 sebanyak 28 responden. Atau dari 52 sampel hanya 18 responden non-obese dan 34 responden sisanya menderita obesitas.

2. Usia Menarche

Berdasarkan tabel 5.4 dari 17 responden hampir seluruh responden 13 $(76,5 \%)$ mengalami usia menarche dini. Menurut Wiknjasastro (2005) bahwa menarche dini merupakan menstruasi yang pertama kali terjadi pada usia $\leq 10$ tahun sedangkan menarche normal terjadi antara usia 11-13 tahun pada remaja putri. Usia menarche dibagi menjadi 3 yaitu dini, normal, dan tarda. Menarche biasanya terjadi dalam rentang usia 10-14 tahun atau pada masa awal remaja. Dari penelitian yang dilakukan oleh peneliti, peneliti memperoleh rata-rata usia menarche dini 10 tahun. Usia tertinggi di usia menarche dini yaitu 10 tahun, sedangkan usia terendah yaitu 9 tahun.

Menarche merupakan suatu tanda awal adanya perubahan lain seperti pertumbuhan payudara dan pertumbuhan rambut daerah pubis. Sejalan dengan 
pertambahan usia seseorang, menarche pun akan berlangsung dengan sendirinya karena menarche merupakan kejadian fisiologis yang dialami oleh seorang wanita yang menginjak masa subur. Hal ini sesuai dengan teori menurut Moersintawati dalam Masruroh (2012) menarche merupakan puncak dari serangkaian perubahan fisiologis yang terjadi pada seorang gadis sedang menginjak dewasa, perubahan timbul karena serangkaian interaksi antara beberapa kelanjar di dalam tubuh. Pusat pengendalian yang utama adalah bagian otak yang disebut hypothalamus, yang bekerja sama dengan kelanjar bawah otak mengendalikan urutan-urutan rangkaian perubahan itu.

Penelitian ini di tunjang oleh hasil survey Arum (2010), di SMPN 12 Kota Batam jumlah keseluruhan murid perempuan kelas 1 adalah 31 orang. Memperoleh hasil dari 12 siswi sebagai sample, 6 siswi mendapatkan menstruasi pertama pada usia kurang dari 10 tahun, 4 siswi mendapatkan menstruasi pertama pada umur 12 tahun, dan 2 siswi mendapatkan menstruasi pertama pada umur 13 tahun.

Penelitian ini di tunjang oleh penelitian Dahliansya (2008), dengan judul Hubungan Indeks Massa Tubuh Dan Persentase Lemak Tubuh Dengan Usia Menarche Dan Keteraturan Siklus Menstruasi (Studi Pada Siswi SMPN I Hulu Gurung Kabupaten Kapuas Hulu Kalimantan Barat Tahun 2007). Hasil penelitian menunjukkan dari 98 responden di dapatkan rata-rata usia menarche dini 9,6 tahun dari $32(32,7 \%)$ responden, menarche normal dengan rata-rata 12,3 tahun dari $59(60,2 \%)$ responden, dan menarche terlambat (tarda) dengan 14,2 tahun dari $7(7,1 \%)$ responden.

Penelitian penunjang lainnya di teliti oleh Saftarina, Fitria (2011) Hubungan Status Gizi dengan Usia Menarche pada Remaja Putri di SMP Negeri 22 Bandar Lampung. Dari data yang diperoleh 78 responden, sebanyak 54 sampel memiliki usia menarche yang normal. Sisanya, 20 responden memiliki usia menarche dini dan 4 responden memiliki usia menarche tarda.

3. Hubungan antara IMT dengan Usia Menarche

Pada proses perhitungan uji statistik Rank Spearman dengan tingkat kemaknaan $\alpha=0,05$ didapatkan $\rho(0,003)<\alpha(0,05)$ maka $\mathrm{H}_{0}$ ditolak $\mathrm{H}_{1}$ diterima. Dengan demikian bahwa penelitian didapatkan $\rho<$ $\alpha$ yang artinya ada Hubungan antara IMT dengan Usia Menarche pada siswi SDN 01Wiyung Surabaya.

Pada tabel 5.5 menunjukkan bahwa dari seluruh responden 13 (100\%), hampir seluruh responden $12(92,3 \%)$ memiliki kategori IMT kegemukan dengan menarche dini.

Asupan gizi yang berlebih dapat mempercepat pembentukan hormonhormon reproduksi yang subur, sehingga dapat mempengaruhi datangnya menarche. Hal ini dapat menyebabkan usia menarche menjadi lebih dini. Sehingga menarche dini dipengaruhi oleh adanya peningkatan berat badan atau kegemukan. Hal ini sependapat dengan (Soetjiningsih, 2004) bahwa asupan nutrisi yang berlebih dapat mempengaruhi kematangan seksual pada gadis yang mendapatkan menstruasi pertama (menarche) lebih dini, sehingga para gadis yang mengalami peningkatan berat badan cenderung mengalami menarche lebih dini, sebaliknya pada gadis yang menstruasinya terlambat, baratnya lebih ringan dari pada yang sudah mestruasi pada usia yang sama, walaupun tinggi badan (TB) meraka sama. Pada umumnya, mereka menjadi matang lebih dini akan memiliki body mass indekx (indeks masa tubuh, IMT) yang lebih tinggi dan mereka yang matang terlambat memiliki IMT lebih kecil pada usia yang sama. Menurut Aishah (2011) mengungkapkan bahwa remaja yang memiliki IMT yang lebih tinggi cenderung mendapatkan menstruasi pertamanya terlebih dahulu, karena kadar leptin yang disekresikan oleh kelenjara diposa. Boenga 
(2011) mengatakan bahwa leptin memengaruhi kadar neuropeptida $\mathrm{Y}$ yang memengaruhi GnRH. Lalu, berubahnya kadar GnRH yang disekresikan juga mengubah kadar sekresi LH. Selainitu, leptin berpengaruh pada maturasi oosit yang merangsang pematangan ovum yang dihasilkan oleh ovarium. Maka dapat disimpulkan bahwa remaja yang memiliki status gizi tinggi akan mengalami menarche di usia yang lebih cepat dibanding mereka yang memiliki status gizi rendah, karena perbedaan jumlah kelenjar adiposa yang mereka punya menghasilkan jumlah sekresi kadar leptin yang berbeda. Mereka yang memiliki status gizi tinggi atau di atas normal akan mendapat menarche di usia yang terlalu cepat, sedangkan mereka yang memiliki status gizi rendah atau di bawah normal mengalami menarche di usia yang terlalu lambat. Lalu, mereka dengan status gizi yang normal mengalami menarche di usia yang juga normal.

Nutrisi dan keadaan semasa zaman anak-anak yang lebih baik membuatkan anak-anak lebih sehat dan mengalami pubertas lebih awal (Pierce dan Leon, 2005). Assosiasi antara indeks massa tubuh (IMT) dan usia menarche berhubungan dengan adipositas dan sekresi gonadotropin. Frisch dan Revelle dalam Karapanou dan Papadimitriou (2010) mengusulkan berat badan kritikal dan kenaikan berat badan berperan untuk usia menarche. Lebih tinggi kadar lemak subkutan dan IMT pada usia prapubertas (5-9 tahun) berassosiasi dengan awal $(<11$ tahun) usia menarche.

Penelitian ini ditunjang oleh penelitian terdahulu yang dilakukan oleh Yosia (2009) dengan judul IMT terhadap usia menarche pada remaja di SMPN 2 Tanjung Morawa Sumatra Utara dengan hasil rata-rata usia menarche 10,5 tahun, tinggi badan 1,48 meter, rata-rata berat badan $55 \mathrm{~kg}$ dan IMTnya $25,45 \mathrm{~kg} / \mathrm{m}^{2}$ yang berarti kegemukan. Sehingga dapat disimpulkan bahwa ada hubungan antara
IMT terhadap usia menarche pada di SMPN 2 Tanjung Morawa Sumatra Utara.

Dari penelitian yang dilakukan oleh Muara (2011), dengan judul IMT dengan Usia menarche pada remaja putri di Kecamatan Secangga Kabupaten Langkat dengan hasil penelitian menunjukkan ratarata usia remaja putri 10,2 tahun, rata-rata tinggi badan $149 \mathrm{~cm}$, rata-rata berat badan $49 \mathrm{~kg}$ dan rata-rata IMT $25,13 \mathrm{~kg} / \mathrm{m}^{2}$ yang berarti kegemukan. Sehingga disimpulkan bahwa ada hubungan antara IMT dengan usia menarche remaja putri di Kecamatan Secangga Kabupaten Langkat.

Penelitian lainnya dilakukan oleh Muhimah (2008), dengan judul hubungan indeks massa tubuh dengan usia menarche pada remaja putri kelas 5 SDN 2 Bangkalan. Hasil penelitian menunjukkan rata-rata usia remaja putri 10,6 tahun, ratarata tinggi badan 1,48 meter, rata-rata berat badan $50 \mathrm{~kg}$ dan rata-rata IMT 25,22 $\mathrm{kg} / \mathrm{m}^{2}$ yang berarti kegemukan. Kesimpulan dari penelitian ini adalah ada hubungan indeks massa tubuh dengan usia menarche pada remaja putri kelas 5 SDN 2 Bangkalan.

Sedangkan dari tabel 5.5 menunjukkan bahwa dari semua 4 (100\%) responden yang mempunyai klasifikasi IMT normal, hampir sebagian besar $3(75 \%)$ responden memiliki usia menarche normal. Hal ini menunjukan bahwa masih ada faktorfaktor lain yang dapat mempengaruhi usia menarche remaja yaitu genetik yang merupakan faktor keturunan yang dibawa oleh individu pada waktu dilahirkan, hormonal berupa kerja hormon estrogen yang dikendalikan oleh hypothalamus, badan yang lemah atau penyakit yang mendera seorang anak gadis seperti penyakit kronis, terutama yang mempengaruhi masukkan makanan dan oksigenasi jaringan dapat memperlambat menarche. Menurut Abdurahman (2004), latihan fisik yang berat dan teratur pada masa prapubertas, dapat menunda terjadinya usia menarche dini. Sedangkan menurut teori dari Waryana (2010), menyatakan bahwa pada remaja putri 
banyak hal-hal yang dapat mempengaruhi menarche, antara lain adanya perubahan hormon yang mempengaruhi kematangan sel dan asupan gizi yang dikonsumsi saat menjelang datangnya menarche.

\section{SIMPULAN}

Berdasarkan tujuan dan hasil yang dicapai dari proses penelitian maka dapat disimpulkan bahwa :

1. Siswi kelas 5 dan 6 SDN 01 Wiyung Surabaya hampir seluruh memiliki klasifikasi IMT kegemukan

2. Siswi kelas 5 dan 6 SDN 01 Wiyung Surabaya hampir seluruh mengalami menarche dini.

3. Ada hubungan antara IMT dengan usia menarche pada siswi kelas 5 dan 6 SDN 01 Wiyung Surabaya

\section{DAFTAR PUSTAKA}

Aminah, Ruhdatul. 2011. Hubungan Usia Menarche dengan Tingkat Kejadian Dismenorhea. http://www.library.upnvcj.ac.id Diakses pada tanggal 08 April 2014 Arikunto, S (2007). Prosedur Penelitian. Jakarta:Rineka Cipta

Arisman. 2004. Gizi dalam Daun Kehidupan, Jakarta: EGC

Atika, P (2010). Obesitas dan gangguan perilaku makanan pada remaja. Yogyakarta

Hurlock, Elisabeth B. 2005. Psikologi Perkembangan Suatu Pendekatan Sepanjang Rentang Kehidupan Edisi Kelima. Jakarta: Erkasse

IDAI. 2008. Tumbuh Kembang Anak dan Remaja. Jakarta: Sagung Seto

Kusmiran, E. 2011. Kesehatan Reproduksi Remaja dan wanita. Jakarta: Salemba Medika

Masruroh, Umi. 2012. Hubungan antara Usia Menarche dengan Usia Menopouse Di BPS Hj. Ari Suprapti Candi Sidoarjo. KTI. UNUSA, Tidak Dipublikasikan

Mengenali Obesitas (2007). Online, http//www.wikipedia.com diunduh pada tanggal 10 mei 2014: 20.30 WIB

Notoatmojo, S . 2002. Metodologi Penelitian kes. PT. Rineka Cipta Nursalam. 2003. Konsep \& Penerapan Metodologi Penelitian Ilmu Keperawatan pedoman skripsi, tesis, dan instrument penelitian keperawatan. Jakarta: Salemba Medika

Proverawati, Atikah, dkk. 2009. Menarche Menstruasi Pertama Penuh Makna. Yogyakarta: Nuha Medika

Proverawati, Atikah, dkk. 2010. Ilmu Gizi untuk Keperawatan dan Gizi Kesehatan. Yogyakarta: Nuha Medika

Pujiani. 2012. Hubungan antara Status Gizi dan Usia Menarche. http://www..kespro.co.id. Diakses pada tanggal 10 Mei 2014

Shandu Sitoyo, H (2014). Pemanfaatan Gizi, Diet dan Obesitas. Yogyakarta: Nuha Medika

Santrock, Jhon W. 2007. Remaja Edisi 11. Jakarta: Erlangga

Saputro, Joko. 2012. Pengertian, Cara Mengukuir dan Faktor yang Mempengaruhi Berat Badan. http://www.jokosaputroblog.wordp ress.com. Diakses pada tanggal 10 Mei 2014

Soetjiningsih. 2004. Tumbuh Kembang Remaja dan Permasalahannya. Jakarta: EGC

Winkjasastro, Hanafi. 2005. Ilmu Kandungan. Jakarta: Sarwono Prewihardjo

Wirakusumah, E.S.2006. Cara aman dan efektif menurunkan berat badan. Jakarta : PT. Gramedi. Pustaka Utama 